\title{
Increasing Student Learning Outcomes in Mathematics About Operational Numbers With Role Playing Method of Colors Media in Class V SDN Karanganyar Gunung 02 Semarang
}

\section{Siti Khuluqul Khasanah}

SDN Karanganyar Gunung 02

sitikhuluqulkag02@gmail.com

\section{Article History}

received 3/12/2020

\begin{abstract}
This study aims to improve the ability to learn mathematics through the media of colored marbles in fifth grade students of SD Karang Anyar Gunung 02 Candisari District, Semarang City. This study uses the Kemmis Taggart class action research method with the stages of planning, implementing, observing and reflecting which consists of two cycles. The subjects of this study were 24 students of class V. Data collection techniques used observation, interviews and documentation. Techniques of data analysis using qualitative analysis. The results of the study showed that out of the 24 students who had completed the pre-cycle, only 11 (45\%) students and 13 (55\%) students had not completed. In the first cycle showed an increase, namely students who completed there were 16 students or (66.67\%) and students who had not completed there were 8 students or (33.33\%), then the results of the improvement in learning cycle II showed an increase, namely students who completed learning there were 23 students or (96\%) and students who have not finished studying there is 1 student or (4\%). Thus the results of the color marbles media method can improve the learning outcomes of fifth grade students at SDN Karanganyar Gunung 02 Semarang in the 2019/2020 academic year.
\end{abstract}

Keywords: mathematics learning outcomes, color marbles role play method, action research

\begin{abstract}
Abstrak
Penelitian ini bertujuan untuk meningkatkan kemampuan pembejaran matematika melalui media kelereng warna pada siswa kelas V SD Karang Anyar Gunung 02 Kecamatan Candisari Kota Semarang. Penelitian ini mengunakan metode penelitian Tindakan kelas model Kemmis Taggart dengan tahapan perencanaan, pelaksanaan, observasi dan refleksi yang terdiri dari dua siklus. Subjek penelitian ini 24 siswa kelas V. Teknik pengumpulan data mengunakan observasi, wawancara dan dokumentasi. Teknik Analisa data mengunakan Analisa kualitatif. Hasil penelitian menunjukan prasiklus menunjukkan dari 24 siswa yang memiliki nilai tuntas hanya $11(45 \%)$ siswa dan sebanyak $13(55 \%)$ siswa belum tuntas. Pada siklus I menunjukkan peningkatan yaitu siswa yang tuntas ada 16 siswa atau (66,67\%) dan siswa yang belum tuntas ada 8 siswa atau (33,33\%), kemudian hasil perbaikan pembelajaran siklus II menunjukkan peningkatan yaitu siswa yang tuntas belajar ada 23 siswa atau (96\%) dan siswa yang belum tuntas belajar ada 1 siswa atau (4\%). Dengan demikian hasil metode media kelereng warna dapat meningkatkan hasil belajar siswa kelas V SDN Karanganyar Gunung 02 Semarang Tahun Pelajaran 2019 / 2020.
\end{abstract}

Kata kunci: hasil belajar matematika, metode role play kelereng warna, penelitian tindakan kelas

Social, Humanities, and Education Studies (SHEs): Conference Series https://jurnal.uns.ac.id/shes

p-ISSN 2620-9284 e-ISSN 2620-9292 


\section{PENDAHULUAN}

Matematika merupakan ilmu yang membahas angka-angka dan perhitungannya, membahas masalah-masalah numerik, mengenai kuantitas dan besaran, mempelajari hubungan pola, bentuk dan struktur, sarana berpikir, kumpulan sistem, struktur dan alat ( Hamzah, 2014: 48 ). Secara garis besar fungsi dari matematika adalah untuk menyelesaikan masalah secara berhitung. Berhitung terdiri dari empat macam, diantaranya adalah menjumlah, mengurang, mengali dan membagi. Hal tersebut tidak bisa terpisahkan dalam pelajaran Matematika pada umumnya dan sudah dipelajari sejak dini.

Matematika selalu dianggap sebagai pelajaran yang sulit dipahami karena berkaitan dengan angka rumus. Pernyataan tersebut dapat dilihat dari hasil yang ada di lapangan yang menunjukkan bahwa hasil belajar matematika pada operasional bilangan bulat di SDN Karanganyar Gunung 02 tergolong rendah karena prosentase menunjukan nilai tertinggi yang diperoleh siswa mencapai 70 dan terendah dari nilai KKM yang mencapai 30. Dari 24 siswa hanya 11 siswa yang mendapat nilai diatas KKM dan selebihnya di bawah KKM. Rendahnya nilai belajar siswa disebabkan oleh beberapa faktor antara lain; metode pembelajaran yang diterapkan di SDN Karanganyar Gunung 02 masih bersifat konvensional dan penggunaan alat peraga/media jarang digunakan, sehingga pemahaman terhadap konsep matematika sulit dicerna. Siswa kurang dilibatkan dalam proses pembelajaran dan cenderung pasif, terbukti dalam kegiatan belajar siswa selalu diam saja ketika mendapatkan kesulitan dalam belajar, siswa selalu menunggu guru untuk memberikan contoh soal dan cara pengerjaannya yang benar tanpa mencoba berpikir untuk menggali dan membangun idenya sendiri, siswa tidak pernah mengajukan pertanyaan yang dianggap kurang dimengerti dan siswa tidak berani menjawab pertanyaan serta mempresentasikan jawaban di depan kelas.

Berdasarkan pengalaman yang peneliti alami pada proses pembelajaran yang tidak optimal, maka peneliti berusaha memperbaiki pembelajaran dengan mengganti metode dan model pembelajaran. Metode yang akan peneliti gunakan adalah role playing dengan bantuan atau media kelereng warna. Hal tersebut bertujuan untuk mengaktifkan dan meningkatkan hasil belajar siswa sesuai dengan yang diharapkan.

Pentingnya pembelajaran bermakna dalam mengajar matematika, karena kebermaknaan pembelajaran akan membuat pembelajaran lebih bermanfaat dan akan lebih mudah dipahami dan diingat oleh siswa. Dalam pembelajaran matematika hendaknya fakta konsep dan prinsip-prinsip fakta tidak diterima secara prosedural tanpa pemahaman dan penalaran. Pengetahuan tidak dapat dipindahkan begitu saja dari otak guru kepada siswa Metode Role Playing atau bermain peran adalah bentuk permainan atau suatu cara penguasaan bahan - bahan pelajaran melalui pengembangan imajinasi dan penghayatan siswa. Pengembangan imajinasi dan penghayatan dilakukan siswa dengan memerankannya sebagai tokoh hidup atau benda mati ( Hamdayama, 2016 ).

Paul D. Diedrich sebagaimana dikutip Sardiman (1992) membuat suatu daftar yang berisi 177 macam kegiatan siswa yang antara lain dapat digolongkan sebagai berikut : 1) Visual activities, yang termasuk di dalamnya misalnya membaca, memperhatikan gambar, demonstrasi, percobaan, pekerjaan orang lain; 2) Oral activities, jenis kegiatan diantaranya, menyatakan, merumuskan, bertanya, memberi saran , mengeluarkan pendapat, diskusi, dan interupsi; 3) Listening activities, sebagai contoh, mendengarkan uraian, percakapan, diskusi, musik, pidato; 3) Writing activities, seperti : menulis cerita, karangan, laporan, angket, menyalin; 4) Motor activities, antara lain : melakukan percobaan, membuat konstruksi, bermain, berkebun, beternak; 5) Mental activities, sebagai contoh : menanggapi, mengingat, memecahkan soal, menganalisa, melihat hubungan, mengambil keputusan; 5) Emotional activities, seperti misalnya ; menaruh minat, merasa bosan. 
Dari uraian di atas, peneliti melihat metode Role Playing atau bermain peran media kelerang warna merupakan metode yang dapat mengakomodir ketujuh aktifitas yang dimaksud. Oleh karena itu peneliti akan meneliti peningkatan hasil belajar matematika melalui role playing media kelerang warna pada siswa kelas V SDN Karanganyar Gunung 02 Kecamatan Candisari Kota Semarang.

\section{METODE}

Metode yang digunakan dalam penelitian adalah metode Penelitian Tindakan Kelas (PTK) model Kemmis dan Taggart. Penelitian ini dilaksanakan di SDN Karanganyar Gunung 02 Kecamatan Candisari Kota Semarang di kelas V pada semester I tahun pelajaran 2019 / 2020 dengan siswa berjumlah 24 orang ( 11 siswi perempuan dan 13 siswa laki-laki ). Penelitian ini dilakukan sebanyak 2 siklus (siklus I dilaksanakan pada hari Selasa, tanggal 27 September 2019 dengan alokasi waktu 2 x 35 menit dan siklus II dilaksanakan hari Selasa, tanggal 4 Oktober 2019 dengan alokasi waktu 2 x 35 menit ). Teknik pengumpulan data mengunakan observasi, wawancara dan dokumentasi. Teknik Analisa data mengunakan analisa kuantitatif.

\section{HASIL DAN PEMBAHASAN}

Penelitian ini dilakukan di SDN Karanganyar Gunung 02 dengan subjek penelitian 24 siswa kelas V SDN Karanganyar Gunung 02. Pelaksanaan PTK ini terdiri dari dua siklus, dimana setiap siklusnya terdiri dari empat tahapan, yaitu proses perencanaan, pelaksanaan, pengamatan dan refleksi sebelum pelaksanaan.

Tabel 1. Daftar Nllai Pra Siklus

\begin{tabular}{|c|c|c|c|c|c|}
\hline \multirow{2}{*}{ No. } & \multirow{2}{*}{ PesertaDidik } & \multirow{2}{*}{ Nilai } & \multirow{2}{*}{ KKM } & \multicolumn{2}{|c|}{ Keterangan } \\
\hline & & & & Tuntas & BelumTuntas \\
\hline 1 & SR & 65 & 65 & $\mathrm{v}$ & \\
\hline 2 & AN & 40 & 65 & & v \\
\hline 3 & $\mathrm{RP}$ & 30 & 65 & & $\mathrm{v}$ \\
\hline 4 & WW & 30 & 65 & & $\mathrm{v}$ \\
\hline 5 & AS & 40 & 65 & & $\mathrm{v}$ \\
\hline 6 & AV & 70 & 65 & $\mathrm{v}$ & \\
\hline 7 & BP & 70 & 65 & $\mathrm{v}$ & \\
\hline 8 & CJ & 60 & 65 & $\mathrm{v}$ & \\
\hline 9 & DR & 65 & 65 & $\mathrm{v}$ & \\
\hline 10 & DA & 65 & 65 & $\mathrm{v}$ & \\
\hline 11 & FR & 65 & 65 & $\mathrm{v}$ & \\
\hline 12 & FS & 30 & 65 & & $\mathrm{v}$ \\
\hline 13 & FA & 40 & 65 & & $\mathrm{v}$ \\
\hline 14 & ID & 30 & 65 & & $\mathrm{v}$ \\
\hline 15 & KA & 50 & 65 & & $\mathrm{v}$ \\
\hline 16 & $\mathrm{Ml}$ & 40 & 65 & & $\mathrm{v}$ \\
\hline 17 & MR & 40 & 65 & & $\mathrm{v}$ \\
\hline 18 & NK & 65 & 65 & $\mathrm{v}$ & \\
\hline 19 & PM & 40 & 65 & & $\mathrm{v}$ \\
\hline 20 & $\mathrm{RR}$ & 65 & 65 & v & \\
\hline 21 & SA & 70 & 65 & $\mathrm{v}$ & \\
\hline 22 & YA & 70 & 65 & $\mathrm{v}$ & \\
\hline 23 & YP & 50 & 65 & & v \\
\hline 24 & ZC & 40 & 65 & & $\mathrm{v}$ \\
\hline & Jumlah & 1230 & & & \\
\hline & Rata - rata & 51,25 & & & \\
\hline & Ketuntasan Klasikal & & & $45 \%$ & $55 \%$ \\
\hline
\end{tabular}


Dari hasil pra siklus dapat dikemukakan bahwa jumlah nilai 1230 dari 31 siswa, sehingga dapat dihitung rata - rata kelas sebesar 51.25. Tingkat ketuntasan klasikal sebelum perbaikan ini mencapai 45\% ( peserta didik yang tuntas ada 11 anak ) dan peserta didik yang belum tuntas ada 13 anak, artinya masih ada $55 \%$ peserta didik yang belum tuntas.

\section{Siklus I}

\section{1) Perencanaan Siklus I}

Siklus ini terdiri dari tahapan sebagai berikut:

a. Perencanaan

1) Mengidentifikasi masalah, mendiagnosis masalah dan menentukan

2) Alternatif pemecahan masalah serta mengembangkannya dimana peneliti dalam hal ini meminta bantuan kepada rekan sejawat dan berkonsultasi dengan pembimbing dalam mengungkapkan dan memperjelas masalah yang peneliti hadapi untuk mencari pemecahannya.

3) Membuat rancangan rencana perbaikan pembelajaran matematika dengan metode role playing dalam pembelajaran.

4) Merancang alat peraga kelereng warna, bahan-bahan seperti uang kelereng,

5) Cat warna merah dan biru serta lembar kegiatan siswa.

6) Menyusun alat observasi sebagai panduan bagi pengamat dalam mengamati pelaksanaan perbaikan pembelajaran.

7) Menyusun tes formatif I.

b. Pelaksanaan

1) Guru menyiapkan rencana perbaikan pelaksanaan pembelajaran.

2) Guru menyiapkan sumber pembelajaran dan soal-soal latihan.

3) Mengadakan presensi siswa.

4) Menyampaikan tujuan pembelajaran, motivasi dan materi pembelajaran dengan menggunakan metode role playing.

5) Guru memberikan tes awal terhadap siswa.

6) Guru menjelaskan kembali materi Operasional Bilangan Bulat.

7) Langkah-langkah menerapkan metode role playing:

a. Guru menyusun / menyiapkan skenario yang akan ditampilkan.

b. Memperkenalkan masalah kontekstual/realistik kepada siswa tentang

c. Materi pokok operasi hitung bilangan bulat yang meliputi pengurutan

d. Bilangan bulat, penjumlahan dan pengurangan bilangan bulat melalui

e. Metode role playing dalam pembelajaran matematika.

f. Menunjuk beberapa siswa untuk mempelajari skenario dalam waktu beberapa hari sebelum pelaksanaan Kegiatan Belajar Mengajar.

g. Guru membentuk kelompok siswa yang anggotanya 3 - 4 siswa.

h. Memberikan penjelasan tentang kompetensi yang ingin dicapai.

i. Memanggil para siswa yang sudah ditunjuk untuk melakonkan skenario yang sudah dipersiapkan.

j. Masing-masing siswa berada di kelompoknya sambil mengamati skenario yang sedang diperagakan.

k. Setelah selesai ditampilkan, masing-masing siswa diberikan lembar kerja untuk membahas / memberi penilaian atas penampilan masing-masing kelompok.

I. Meminta setiap kelompok untuk mempresentasikan hasil diskusi dan memberikan kesempatan kelompok lainnya untuk bertanya, mengungkapkan kritik dan saran.

8) Membimbing siswa untuk menyimpulkan materi pelajaran.

9) Pada akhir siklus I, siswa mengerjakan tes formatif I.

c. Pengamatan

1) Hasil Belajar Siswa
a) Rata-rata kelas. 
b) Banyaknya siswa yang tuntas belajar (skor $\geq 65$ )

2) Aktivitas siswa

a) Pemahaman terhadap materi yang disampaikan guru.

b) Keaktifan siswa dalam bertanya kepada guru.

c) Keberanian siswa dalam mengemukakan pendapat.

d) Keberanian siswa dalam mempresentasikan hasil kerja.

e) Ketekunan siswa dalam menyelesaikan tugas dari guru.

f) Tahap-tahap yang dilakukan siswa dalam menyelesaikan soal operasi hitung bilangan bulat.

g) Kerjasama siswa pada saat bekerja kelompok.

3) Performansi guru dalam pembelajaran

a) Penguasaan materi.

b) Penguasaan penggunaan model pembelajaran matematika role playing.

\section{d. Refleksi}

Refleksi merupakan langkah untuk menganalisis semua kegiatan yang dilakukan pada siklus I. Analisis dilakukan untuk mengetahui kelebihan dan kekurangan unsur-unsur yang diamati pada siklus I, dalam refleksi peneliti berdiskusi dengan teman sejawat serta konsultasi dengan pembimbing untuk mengkaji semua temuan, baik kekurangan maupun kelebihan pada proses perbaikan pembelajaran pada siklus I. Dari hasil diskusi diperoleh refleksi sebagai berikut :

a) Meningkatnya motivasi dan gairah belajar siswa.

b) Tumbuhnya keberanian siswa untuk mengungkapkan pendapat.

c) Siswa mulai terlihat aktif dalam proses pembelajaran.

Tabel 2. Hasil Siklus I

\begin{tabular}{|c|c|c|c|c|c|}
\hline \multirow{2}{*}{ No. } & \multirow{2}{*}{ Peserta Didik } & \multirow{2}{*}{ Nilai } & \multirow{2}{*}{ KKM } & \multicolumn{2}{|c|}{ Keterangan } \\
\hline & & & & Tuntas & Belum Tuntas \\
\hline 1 & SR & 75 & 65 & $\mathrm{v}$ & \\
\hline 2 & AN & 60 & 65 & & $\mathrm{v}$ \\
\hline 3 & $\mathrm{RP}$ & 65 & 65 & $\mathrm{v}$ & \\
\hline 4 & WW & 55 & 65 & & $\mathrm{v}$ \\
\hline 5 & AS & 65 & 65 & v & \\
\hline 6 & $\mathrm{AV}$ & 75 & 65 & $\mathrm{v}$ & \\
\hline 7 & $\mathrm{BP}$ & 75 & 65 & $\mathrm{v}$ & \\
\hline 8 & CJ & 75 & 65 & $\mathrm{v}$ & \\
\hline 9 & DR & 75 & 65 & $\mathrm{v}$ & \\
\hline 10 & DA & 80 & 65 & $\mathrm{v}$ & \\
\hline 11 & FR & 65 & 65 & $\mathrm{v}$ & \\
\hline 12 & FS & 50 & 65 & & $\mathrm{v}$ \\
\hline 13 & FA & 65 & 65 & $\mathrm{v}$ & \\
\hline 14 & ID & 65 & 65 & $\mathrm{v}$ & \\
\hline 15 & $\mathrm{KA}$ & 55 & 65 & & $\mathrm{v}$ \\
\hline 16 & $\mathrm{Ml}$ & 50 & 65 & & $\mathrm{v}$ \\
\hline 17 & MR & 55 & 65 & & $\mathrm{v}$ \\
\hline 18 & NK & 75 & 65 & $\mathrm{v}$ & \\
\hline 19 & PM & 65 & 65 & $\mathrm{v}$ & \\
\hline 20 & $\mathrm{RR}$ & 75 & 65 & $\mathrm{v}$ & \\
\hline 21 & SA & 75 & 65 & $\mathrm{v}$ & \\
\hline 22 & YA & 80 & 65 & $\mathrm{v}$ & \\
\hline 23 & YP & 60 & 65 & & $\mathrm{v}$ \\
\hline 24 & ZC & 60 & 65 & & $\mathrm{v}$ \\
\hline & Jumlah & 1595 & & & \\
\hline & Rata - rata & 66.45 & & & \\
\hline & Tingkat Ketuntasan Klasikal & & & $66,67 \%$ & $33,33 \%$ \\
\hline
\end{tabular}


Dengan melihat tabel di atas dapat diketahui bahwa sebelum perbaikan pembelajaran nilai rata - rata kelas hanya 51,25 dengan prosentase tingkat ketuntasan klasikal $45 \%$. Hal tersebut menunjukkan bahwa tarap serap masih jauh dari target yang harus dicapai. Setelah diadakan perbaikan pembelajaran pada Siklus I, diperoleh rata rata kelas 66,45 dengan tingkat ketuntasan klasikal mencapai $66,67 \%$. Ini berarti ada kenaikan rata rata kelas sebesar 15 dan kenaikan tingkat ketuntasan klasikal sebesar $21.67 \%$. Hal tersebut menunjukkan bahwa perbaikan pembelajaran pada Siklus I belum berhasil

\section{Siklus II}

Atas dasar hasil refleksi pada proses perbaikan pembelajaran pada siklus I, maka peneliti mengembangkan rencana perbaikan pembelajaran berupa perencanaan, pelaksanaan, pengamatan dan refleksi.

\section{a. Perencanaan}

1) Mengidentifikasi masalah dan merumuskan masalah berdasarkan refleksi pada siklus I.

2) Merancang rencana perbaikan pembelajaran sesuai dengan hasil refleksi siklus I.

3) Merancang alat peraga kelereng warna serta lembar kegiatan siswa.

4) Menyusun lembar pengamatan aktivitas belajar siswa dan performansi

5) Guru.

6) Menyusun tes formatif II.

b. Pelaksanaan

1) Menyiapkan rencana pelaksanaan pembelajaran.

2) Menyiapkan sumber pembelajaran dan soal-soal latihan.

3) Mengadakan presensi siswa.

4) Menyampaikan tujuan pembelajaran, motivasi dan materi pembelajaran dengan menggunakan metode role playing dalam pembelajaran matematika.

5) Langkah-langkah menerapkan metode role playing dalam pembelajaran :

a. Guru menyusun / menyiapkan skenario yang akan ditampilkan.

b. Memperkenalkan masalah kontekstual / realistik kepada siswa tentang materi pokok operasi hitung bilangan bulat yang meliputi pengurutan bilangan bulat, penjumlahan dan pengurangan bilangan bulat melalui metode role playing media kelereng warna pada pembelajaran matematika.

c. Menunjuk beberapa siswa untuk mempelajari skenario dalam waktu beberapa hari sebelum pelaksanaan Kegiatan Belajar Mengajar.

d. Guru membentuk kelompok siswa yang anggotanya 3 - 4 siswa.

e. Memberikan penjelasan tentang kompetensi yang ingin dicapai.

f. Memanggil para siswa yang sudah ditunjuk untuk melakonkan skenario yang sudah dipersiapkan.

g. Memfasilitasi setiap kelompok dengan kelereng warna.

h. Masing-masing siswa berada di kelompoknya sambil mengamati skenario yang sedang diperagakan.

i. Setelah selesai ditampilkan, masing-masing siswa diberikan lembar kerja untuk membahas / memberi penilaian atas penampilan masing-masing kelompok.

j. Mengawasi, dan membimbing siswa yang mengalami kesulitan belajar serta mengamati aktivitas belajar siswa dalam kelompok.

k. Meminta setiap kelompok untuk mempresentasikan hasil diskusi dan memberikan kesempatan kelompok lainnya untuk bertanya, mengungkapkan kritik dan saran.

6) Membimbing siswa untuk menyimpulkan materi pelajaran.

7) Pada akhir siklus II, siswa mengerjakan tes formatif II.

c. Pengamatan

1) Hasil Belajar Siswa

a) Rata-rata kelas. 
b) Banyaknya siswa yang tuntas belajar (skor $\geq 65$ )

2) Aktivitas siswa
a) Pemahaman terhadap materi yang disampaikan guru.
b) Keaktifan siswa dalam bertanya kepada guru.
c) Keberanian siswa dalam mengemukakan pendapat.
d) Keberanian siswa dalam mempresentasikan hasil kerja.
e) Ketekunan siswa dalam menyelesaikan tugas dari guru.
f) Tahap-tahap yang dilakukan siswa dalam menyelesaikan soal operasi hitung bilangan bulat.
g) Kerjasama siswa pada saat bekerja kelompok.

3) Performansi guru dalam pembelajaran
a) Penguasaan materi.
b) Penguasaan penggunaan model pembelajaran matematika tentang operasional hitung bilangan bulat menggunakan metode role playing media kelereng warna.

\section{d. Refleksi}

Pada refleksi siklus II ini mendapatkan hasil temuan sebagai berikut :

Siswa lebih mudah memahami materi tentang Operasional Bilangan Bulat.

Hasil belajar siswa sudah memenuhi kriteria ketuntasan minimal yang guru tetapkan [ perbaikan pembelajaran pada siklus II sudah berhasil ].

Tabel 3. Hasil Siklus II

\begin{tabular}{|c|c|c|c|c|c|}
\hline \multirow{2}{*}{ No. } & \multirow{2}{*}{ Peserta Didik } & \multirow{2}{*}{ Nilai } & \multirow{2}{*}{ KKM } & \multicolumn{2}{|c|}{ Keterangan } \\
\hline & & & & Tuntas & Belum Tuntas \\
\hline 1 & SR & 80 & 65 & $\mathrm{v}$ & \\
\hline 2 & AN & 70 & 65 & $\mathrm{v}$ & \\
\hline 3 & $\mathrm{RP}$ & 75 & 65 & $\mathrm{v}$ & \\
\hline 4 & WW & 65 & 65 & $\mathrm{v}$ & \\
\hline 5 & AS & 75 & 65 & $\mathrm{v}$ & \\
\hline 6 & AV & 90 & 65 & $\mathrm{v}$ & \\
\hline 7 & $\mathrm{BP}$ & 90 & 65 & $\mathrm{v}$ & \\
\hline 8 & CJ & 85 & 65 & $\mathrm{v}$ & \\
\hline 9 & DR & 85 & 65 & $\mathrm{v}$ & \\
\hline 10 & DA & 85 & 65 & $\mathrm{v}$ & \\
\hline 11 & FR & 80 & 65 & $\mathrm{v}$ & \\
\hline 12 & FS & 70 & 65 & $\mathrm{v}$ & \\
\hline 13 & FA & 85 & 65 & $\mathrm{v}$ & \\
\hline 14 & ID & 75 & 65 & $\mathrm{v}$ & \\
\hline 15 & $\mathrm{KA}$ & 75 & 65 & $\mathrm{v}$ & \\
\hline 16 & MI & 60 & 65 & & $\mathrm{v}$ \\
\hline 17 & MR & 75 & 65 & $\mathrm{v}$ & \\
\hline 18 & $\mathrm{KV}$ & 80 & 65 & $\mathrm{v}$ & \\
\hline 19 & PM & 75 & 65 & $\mathrm{v}$ & \\
\hline 20 & $\mathrm{RR}$ & 75 & 65 & $\mathrm{v}$ & \\
\hline 21 & SA & 90 & 65 & $\mathrm{v}$ & \\
\hline 22 & YA & 90 & 65 & $\mathrm{v}$ & \\
\hline 23 & YP & 70 & 65 & $\mathrm{v}$ & \\
\hline 24 & ZC & 70 & 65 & $\mathrm{v}$ & \\
\hline & Jumlah & 1870 & & & \\
\hline & Rata - rata & $77,91 \%$ & & & \\
\hline & Ketuntasan Klasikal & & & $96 \%$ & $4 \%$ \\
\hline
\end{tabular}

Dari tabel 3 di atas, dapat dikemukakan bahwa setelah perbaikan pembelajaran Siklus I diperoleh nilai rata - rata kelas 66,45 dengan tingkat ketuntasan klasikal $66,67 \%$. Selanjutnya setelah diadakan perbaikan pembelajaran Siklus II diperoleh nilai 
rata - rata kelas 77,91 dan kenaikan tingkat ketuntasan klasikal 29,33\%. Dengan tercapainya tingkat ketuntasan klasikal mencaai $96 \%$ berarti perbaikan pembelajaran pada Siklus II sudah berhasil.

Disamping disajikan data nilai rata - rata kelas dan tingkat ketuntasan klasikal, berikut ini disajikan daftar rekapitulasi nilai hasil evaluasi belajar setelah perbaikan pembelajaran Siklus II pada tabel 4.

Tabel 4. Daftar Rekapitulasi Nilai Hasil Evaluasi Sebelum ( Pra Siklus ) dan Setelah Perbaikan Pembelajaran Siklus I dan Siklus II

\begin{tabular}{ccccc}
\hline & & \multicolumn{3}{c}{ Banyak Siswa } \\
\cline { 3 - 5 } No & Interval Nilai & Pra Siklus & $\begin{array}{c}\text { Perbaikan } \\
\text { Siklus I }\end{array}$ & $\begin{array}{c}\text { Perbaikan } \\
\text { Siklus II }\end{array}$ \\
\hline 1. & Nilai $<64$ & 13 & 8 & 1 \\
2. & $65-80$ & 11 & 16 & 14 \\
3. & $81-100$ & 0 & 0 & 9 \\
Jumlah & & 24 & 24 & 24 \\
\hline
\end{tabular}

Berdasarkan hasil analisis ataupun refleksi pada pra siklus, siklus I dan II terhadap hasil belajar siswa dalam kompetensi Operasional Bilangan Bulat kelas V SDN Karanganyar Gunung 02 Kecamatan Candisari Kota Semarang semester 1 mengalami peningkatan. Menurut seorang ahli bernama Adi S, (2003: 67 ) peningkatan merupakan upaya untuk menambah derajat, tingkat, dan kualitas maupun kuantitas. Peningkatan juga dapat berarti penambahan keterampilan dan kemampuan agar menjadi lebih baik. Selain itu, peningkatan juga berarti pencapaian dalam proses, ukuran, sifat, hubungan dan sebagainya. Sehingga bisa dikatakan hasil belajar siswa dalam kompetensi Operasional Bilangan Bulat kelas V SDN Karanganyar Gunung 02 Kecamatan Candisari Kota Semarang semester 1 sudah meningkat sesuai harapan. Pada tabel 4 di atas dapat dilihat bahwa banyaknya siswa yang memeroleh nilai $<65$ semakin menurun jumlahnya. Pada pra siklus terdapat 13 siswa yang memperoleh nilai di bawah 65, setelah perbaikan pembelajaran Siklus I berjumlah 8 siswa, dan pada pembelajaran Siklus 2 menurun menjadi 1 siswa. Demikian pula sebaliknya, siswa yang memperoleh nilai $65 \leq$ nilai $\leq 100$ semakin bertambah. Pada pra siklus terdapat 11 siswa yang memperoleh nilai di atas 65, setelah perbaikan pembelajaran Siklus I hanya 16 siswa, dan perbaikan pembelajaran Siklus II jumlahnya semakin bertambah menjadi 23 siswa.

\section{SIMPULAN}

Berdasarkan data yang telah dianalisis pada bab sebelumnya, peneliti dapat membuat kesimpuln bahwa penelitian tindakan krlas itu efektif untuk meningkatkan hasil belajar siswapada mata pelajaran Matematika tentang operasional bilangan bulat dengan metode role playing media kelereng warna di kelas V SDN Karanganyar Gunung 02 Semarang tahun pelajaran 2019 / 2020. Hal tersebut dapat dilihat dari hasil akhir pada pra siklus, siklus I dan siklus II. Pada pra siklus, jumlah siswa yang mendapat nilai di atas KKM hanya 11 siswa dengan rata rata 51,25 dan tingkat ketuntasannya adalah $45 \%$. Itu menunjukkan bahwa hasil belajar siswa sangat jauh dari rata rata. Sedangkan pada siklus I menunjukkan adanya peningkatan pada hasil belajar siswa meskipun belum maksimal, yaitu 66,45 pada hasil rata rata kelas dan $66,67 \%$ untuk prosentase ketuntasan klasikal kelas. Berdasarkan data pada siklus I dapat kita bandingkan pula dengan hasil belajar pada siklus II, dimana hasil belajar pada siklus II mengalami peningkatan yang signifikan. Hasil rata rata kelas pada siklus II yaitu 77,91 dengan tingkat ketuntasan klasikal yaitu $96 \%$.

Dengan adanya hasil tersebut, peneliti menyimpulkan bahwa berdasarkan perbedaan ketiga siklus menunjukkan bahwa ada perbedaan hasil belajar siswa antara 
pembelajaran secara konvensional dengan pembelajaran menggunakan metode role playing yang menunjukkan keefektifannya dalam pembelajaran.

\section{DAFTAR PUSTAKA}

Kim, C., Mirusmonov, M., Lee, I. (2010). An Empirical Examination of Factors Influencing the Intention to Use Mobile Payment. Computers in Human Behavior, 26 (1), 310-322.

Adi, S. Pengertian Peningkatan Menurut Ahli. ( 08 Agustus 2014 ),

http://www.duniapelajar.com.pengertian-peningkatan-menurut-para-ahli.html

Arikunto, Suharsimi. 2010. Prosedur Penelitian: Suatu Pendekatan Praktek. Jakarta. PT. Rineka Cipta.

BSNP. 2006. Standar Isi dan SKL Untuk Satuan Pendidikan Dasar SD/MI. Jakarta: Cipta Jaya.

BSNP. 2007. Standar Kompetensi dan Kompetensi Dasar Tingkat SD/MI. Jakarta: Depdiknas.

Depdiknas. 2006. Kurikulum Tingkat Satuan Pendidikan ( KTSP ). Jakarta: Departemen Pendidikan Nasional.

Hamalik Oemar. 2005. Metode Belajar dan Kesulitan -Kesulitan Belajar. Bandung: Tarsito.

http://www.belajarpsikologi.com/macam-macam-teori-belajar/

http://www.rumusmatematikadasar.com/2014/09/pengertian-matematika-menurutpendapat-ahli-dan-kurikulum.html? $\mathrm{m}=1$

Muhsetyo, Gatot, dkk. 2007. Pembelajaran Matematika SD. Jakarta: Universitas Terbuka .

Sardiman, A.M. Interaksi dan Motivasi Belajar Mengajar. Jakarta: CV. Rajawali.

Subarinah Sri. 2006. Inovasi Pembelajaran Matematika SD. Jakarta: Depdiknas. 